\title{
UNDERSTANDING HISTORY OF ARCHITECTURE THROUGH LOST CITIES, CASE: CAHOKIA CIVILIZATION
}

\author{
Gaurab Das Mahapatra ${ }^{1}$, Tapasya Mukammala ${ }^{2,}$ Diksha Jain $^{3}$ \\ ${ }^{1}$ Assistant Professor, Gitam School of Architecture, Gitam University Andhra Pradesh, India \\ ${ }^{2} 4^{\text {th }}$ Year Student, Gitam School of Architecture, Gitam University Andhra Pradesh, India \\ ${ }^{3} 1^{\text {st }}$ Year Student, Gitam School of Architecture, Gitam University Andhra Pradesh, India
}

\begin{abstract}
It is the people that make history. The lives of people living in the past has shaped what today is left is as a larger world. Every civilization has its own historic implications. Understanding the history of architecture is an important tool for contemporary design. In the present state of rapid modernization, we have started to embrace the future but have forgotten that detailed analysed history is what leads us to a better tomorrow. These studies are essentially a comparison between how the people lived and how they wanted to be perceived as a living. Apart from known and architecturally celebrated ancient towns like Mohen-jodaro, Harappa etc., there lies an unending list of mysterious cities like Atlantis, Kahokia, Catalhoyk, Pavlopetri, Tikal, Timgad, Machu Pichu, etc. They are still under research as relevant and requisite data to get them included in textbooks are still missing. However, each of these places has a unique story of its own. Each of them is like fairy tale story with charm and ecstasy. Their lifestyle, neighbourhood, habits, strengths and downfall are all very relevant to their socio-economic setting. An in-depth analysis of their civilization will certainly help us in establishing a better understanding of the human race as a whole. This in turn would help us in designing future cities. This paper will involve the study and analysis of Kahokia civilization with reference to various aspects of architecture and socio-economic setting. A journey of their rise and fall is being attempted to be traced and analysed.
\end{abstract}

Keywords: History, Mystery, Unique, Architecture, Socio-economic, Future, Kahokia.

\section{INTRODUCTION}

Cahokia, the largest earthen monument of North America also known as the City of the Sun holds mysteries like no other lost city -
How it was planned? How it was built? What it meant to its people?

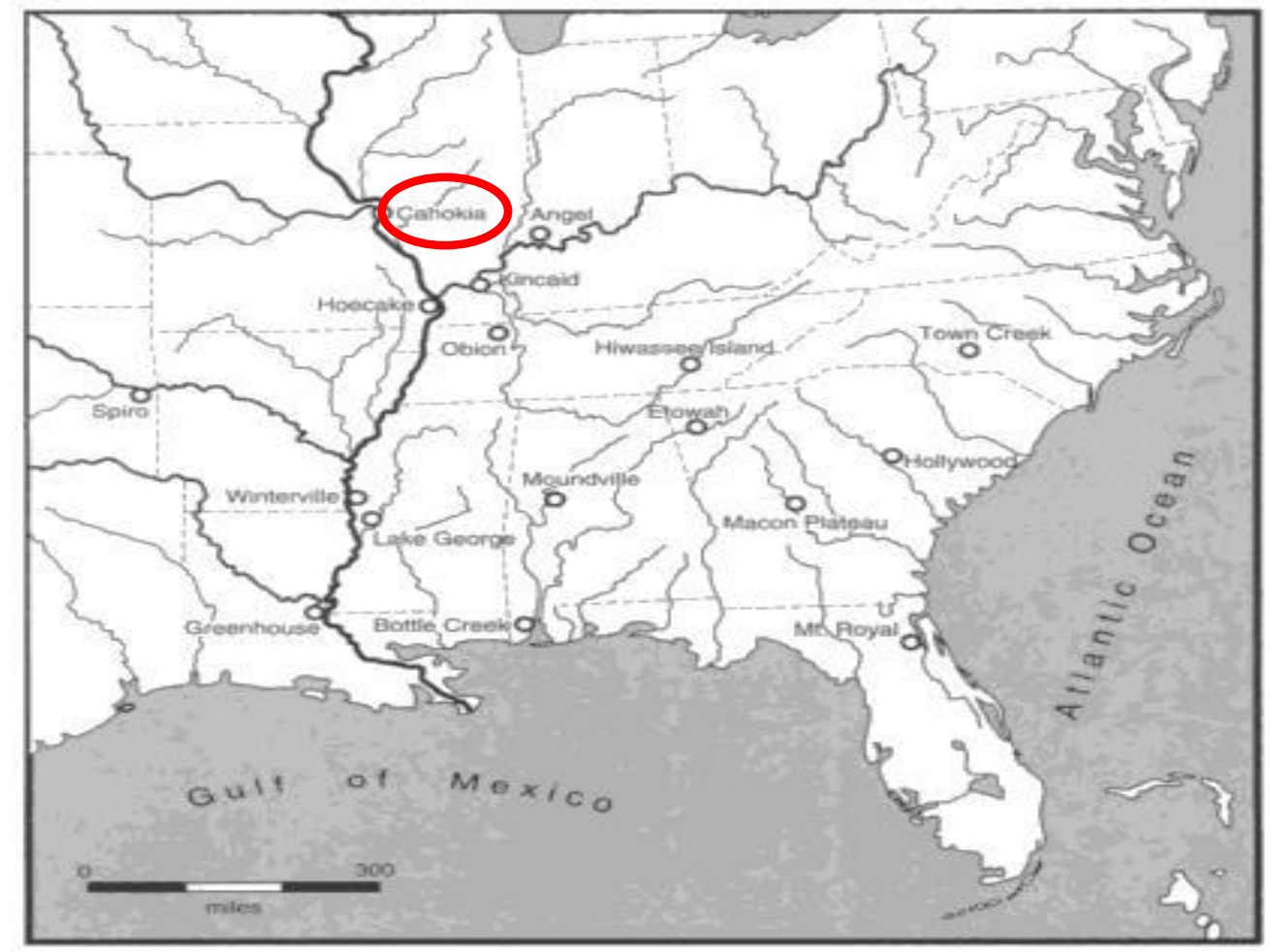

Fig 1: Map showing Cahokia Civilization 


\section{LIFESTYLE}

A huge mound, largest lost city of North America, and a vast series of smaller mounds arranged in patterns across the archaeological site situated in the north of Mexico pointed to a far reaching enterprise, to people who had a vision of what they would build, and a city like no other in its time [1].

This valley was rich and naturally abundant. Its fertile soil and the mighty Mississippi are hospitable to a vast range of plant species. The river would flood all the nearby plains. It provided different natural habitats for a wide array of animals. It was a habitat also for humans over 12000 years ago. Over thousands of years, people have evolved and so has the Mississippian culture. The Mississippians built mounds, grew squash, sun - flowers and seed - bearing plants. Wild plants, fish, animals, were also important food but the fuel for the great enterprise was nothing but agriculture. They started cultivating corn. Corn grew profusely in the area producing more food than needed surplus. Crop yield were high. They could be stored for a long time. They could be saved for years when the crops were poor. The steady food supply and the great number of people made Cahokia their permanent home [1].

The people of Cahokia exchanged surplus crops for meat, tools and clothing. Such a huge production of corn meant that some people did not need to farm. They specialised in tool - making. Corn and crops became more than just foods. They were the fuel for the whole society. The leader of the clan used corn for a variety of purposes. He traded them for rare and exotic goods, for metals like copper and sea shells. The city of Cahokia traded this way for over a network that span thousands of miles, from the great lake to the gulf of Mexico, from the Atlantic ocean to far beyond [1].

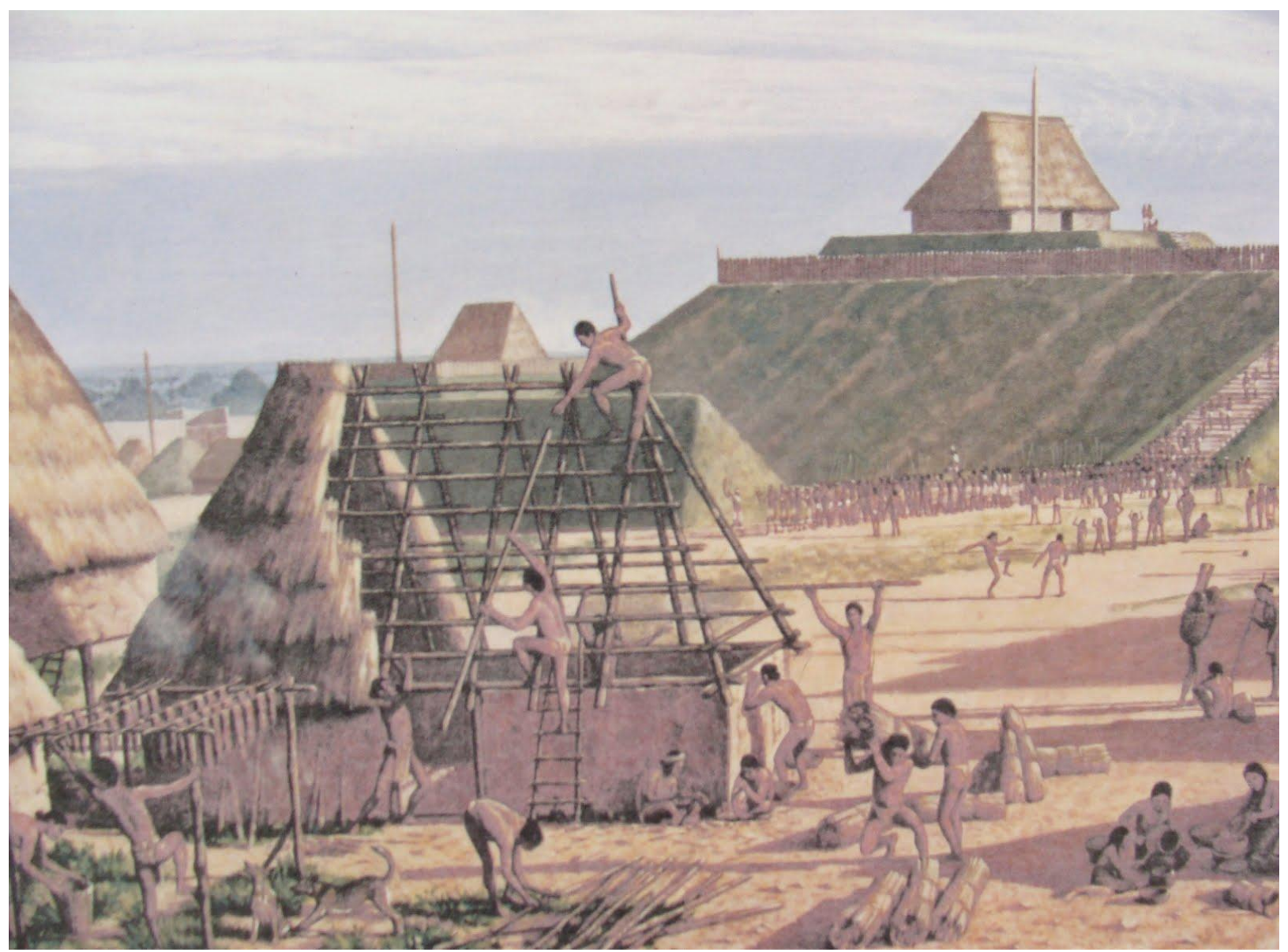

Fig 1 : A typical Cahokia settlement

\section{SETTLEMENT PATTERN}

All these communities were a part of the Mississippian tradition. The larger communities such as Cahokia, built massive flat top mounds. Huge platforms of earth were built where temples and other buildings were erected. In the American bottom region, where the Mississippian Missouri Rivers converged, there was an even linked network. The small communities where few houses were planted at the edge of a corn field were linked to larger villages which were linked to still larger cities with thousands of residents. At the centre of them all was Cahokia [2]. 


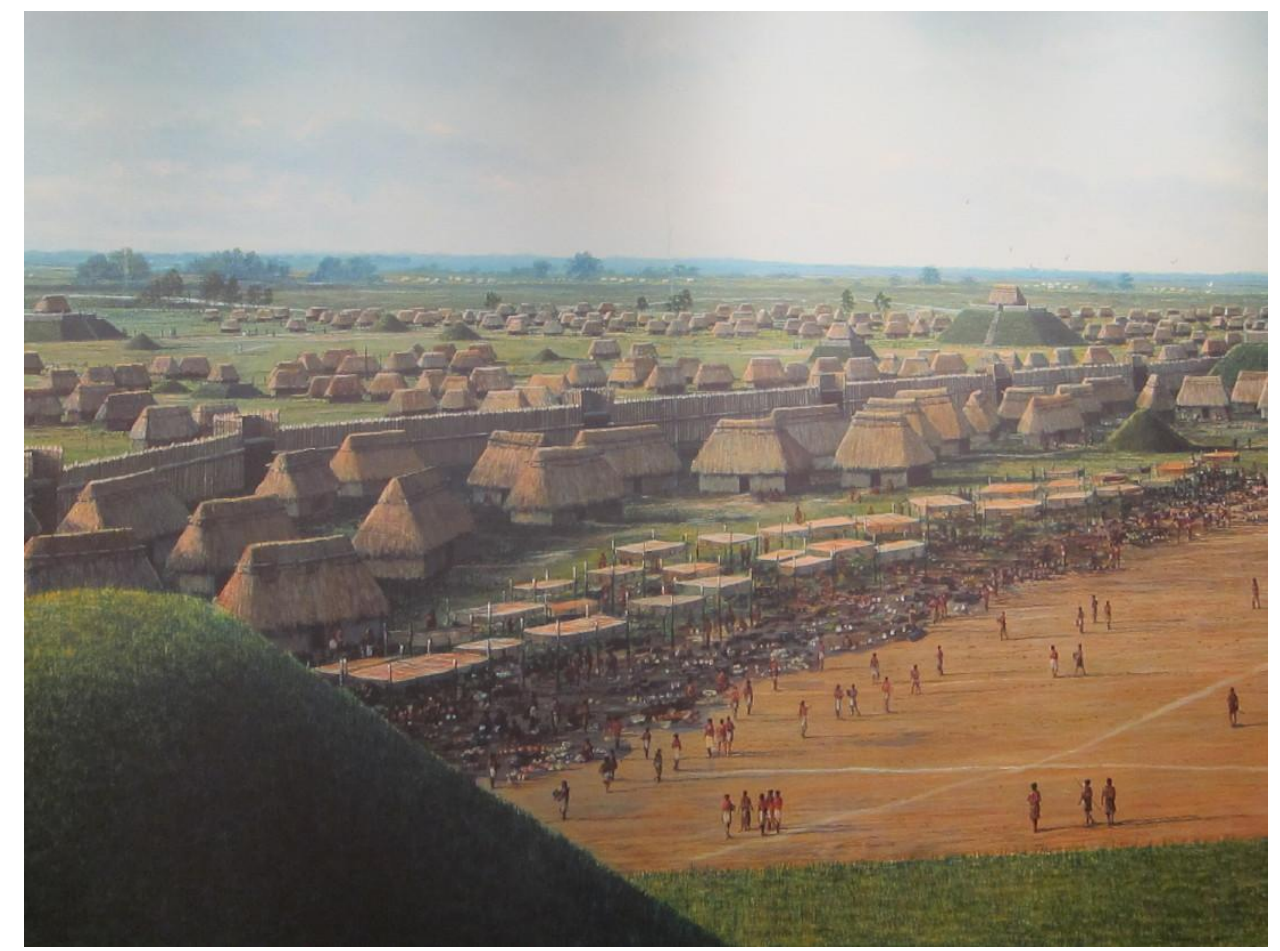

Fig 2 : City boundaries

Cahokia represented great mounds, vast ceremonial plazas and hoses as far as the eye could behold. It was the seed of power, vitality, wealth and security. The city by some means prevailed for several hundred years. Many of its parts were cited with great and deliberate precision. Each area had its individuality - its own function. There were enormous plazas for games, ceremonies and gatherings. They built a miles long wall protecting the ceremonial area. They had unique sun calendars which came to be known as wood hinge. They had corn fields and other crop fields so immeasurable that it fed its 20000 inhabitants and also produced surplus. Cahokia had immense pits and from these the earth for the mounds was dug. They built the rich top mounds that marked the city's boundaries. They had the flat top mounds where the buildings stood. And they also have the conical burial mounds. Nevertheless, there was one mound, greatest of all in the whole Mississippian world, located at the centre of the city; it also marked the city's highest point. It was the abode to the chief who ruled the earth and spoke to the sky [3].

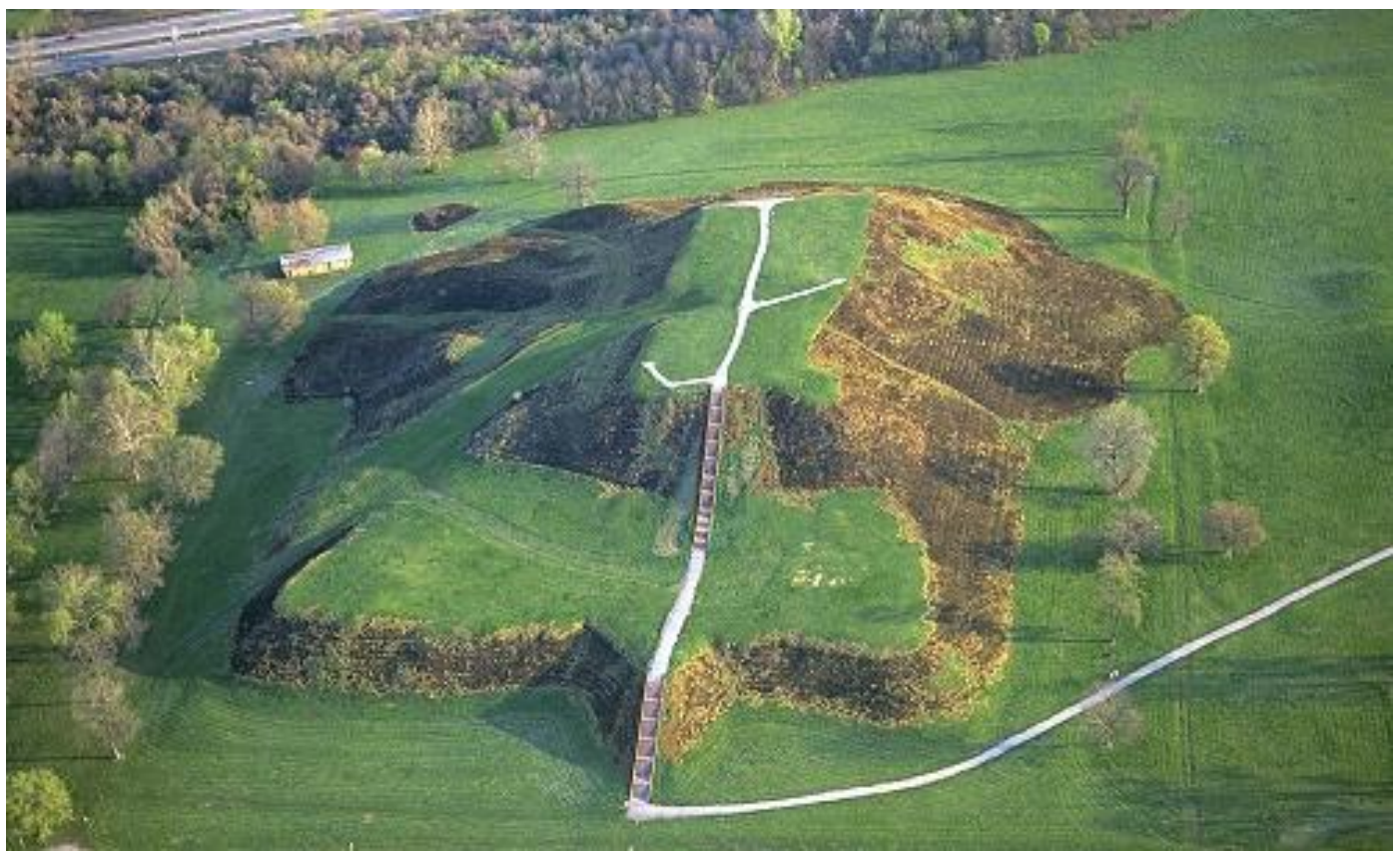

Fig 3 : Large Mounds 


\section{THE CHIEF}

It is known that he had immeasurable wealth, profound wisdom and unquestionable authority. $\mathrm{He}$ was held responsible for maintaining between the spiritual forces of the upper world and the lower world. Most importantly he was responsible for maintaining order and harmony among people. Service rendered to him was considered as service rendered to God. With his wisest advisers, he directed the construction of mounds, the site of his temples. For thousands of people, building mounds was an act of loyalty or faith [3].

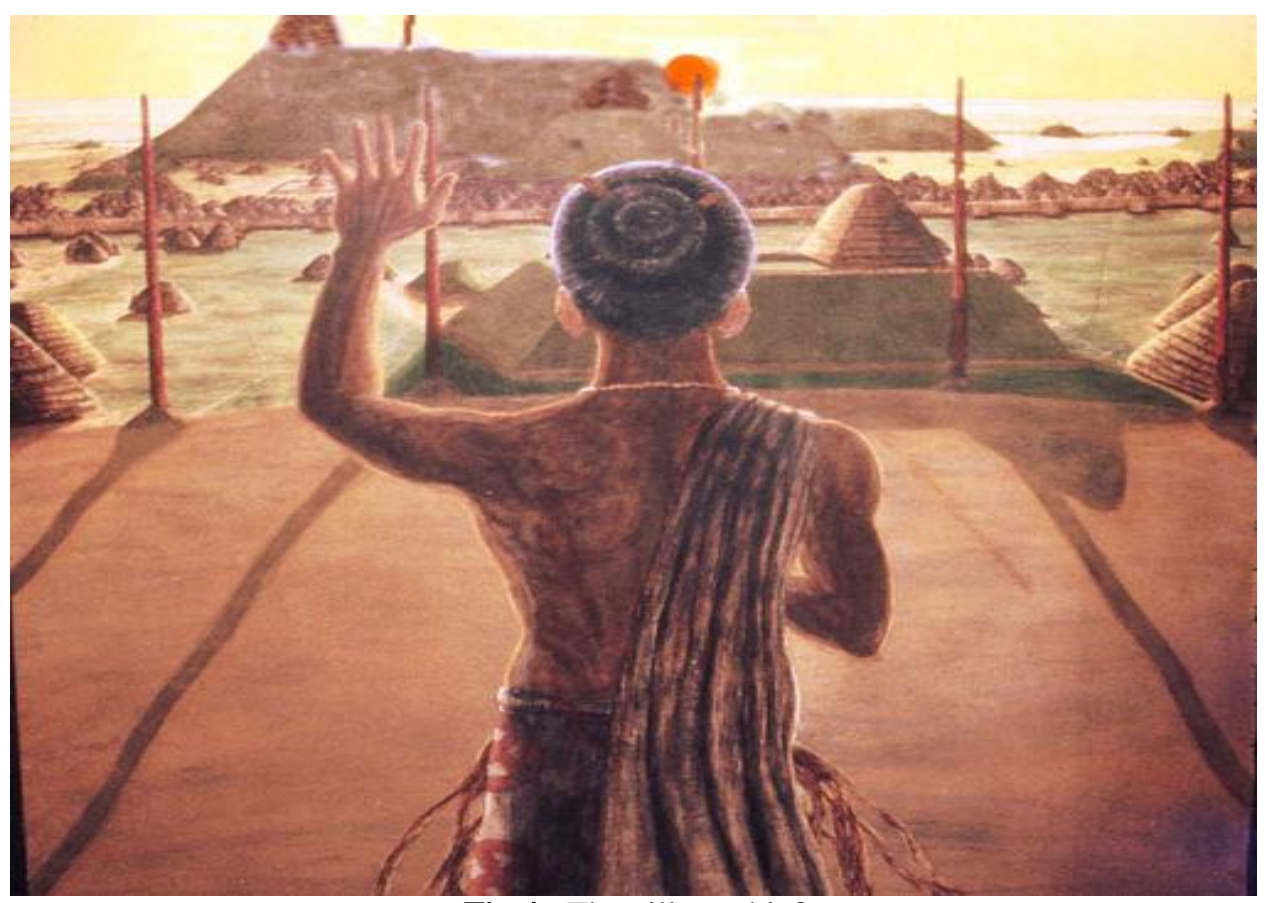

Fig 4 : The village chief

\section{BUILDING STAGES AND RISE OF \\ sixty pounds at a time. They watched the great mound as it grew over the years, proudly [4].} URBANISM

The Mississippians dug the earth with stone holes and carried mud on their backs and woven baskets - fifty to

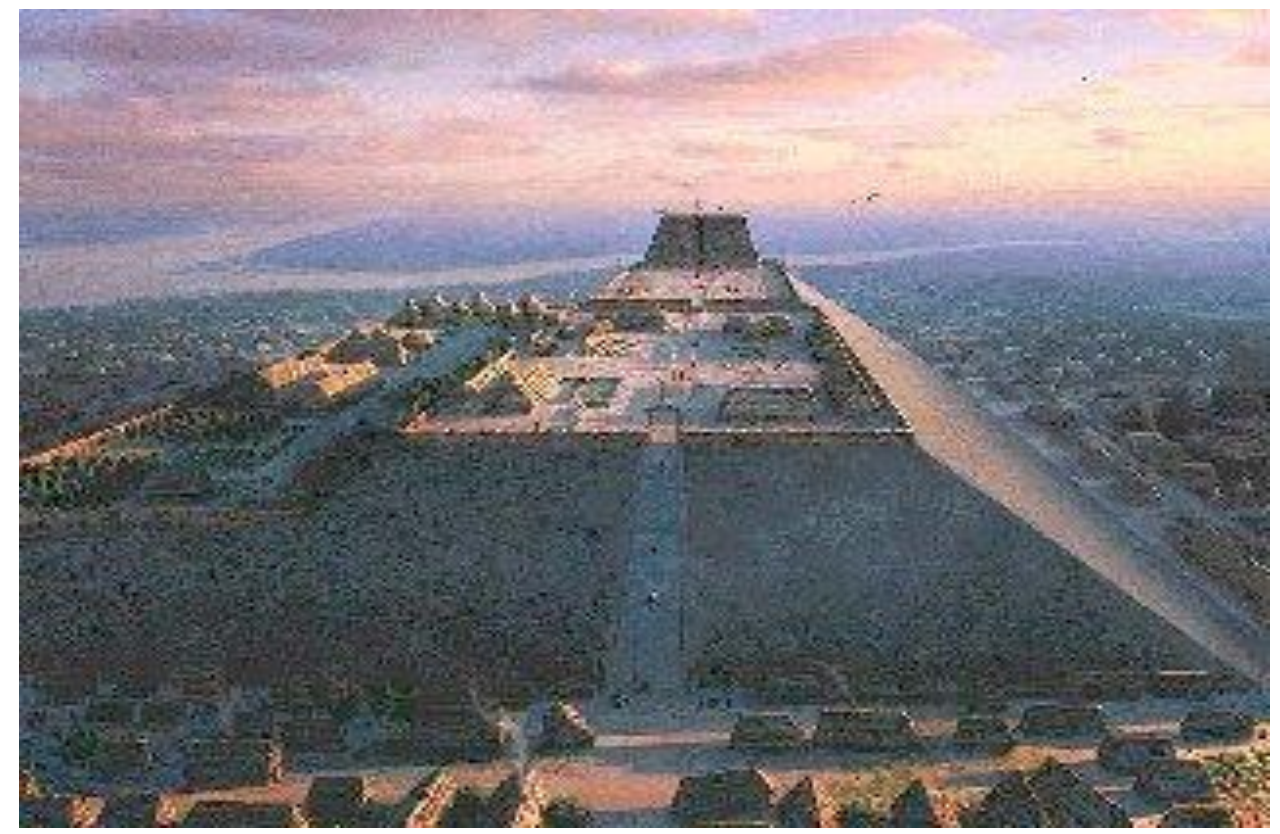

Fig 5 : The Great Mound 
Cahokia had now become a busy place bustling with human energy. The people made and used tools, obtained and prepared food, built houses and other structures. The city struggled with all the by - products of an urban life garbage, crime, population increase, exhaustion of resources, diseases, malnutrition and the list goes on. They raised their children, nursed the sick and buried the dead. As the population grew, the city also grew in complexity. A family which was earlier self - sustainable now had to trade and work with other clans and families to survive. Relationships grew, within and beyond the family. There was a web of interdependence for the people of Cahokia within the community. Each day was a challenge to the body, mind and spirit. Similar to the way the whole world struggles to understand it, these people used their myths and beliefs to do so [4].

\section{BELIEFS}

In the seen and unseen aspects, it is known and unknown nature, we find clues about their beliefs in the rituals they performed and in the symbols they used. A seed is buried like a friend who has passed away. From it, grows a new plant which is ripened and harvested so that the seed may be planted again [5]. This suggests they believe in a life that is followed by death and a death that is followed by life. It is a cycle never - ending. Consider the snake under the earth which can be seen to emerge from its own dead skin wearing a fresh new one. On witness, the sun gives off fire and new life advancing across the heavens in a perfect predictable arch. They used the sun's path to chart the seasons, to mark that the day and night are equal and also used it to measure the cycles of life [6].

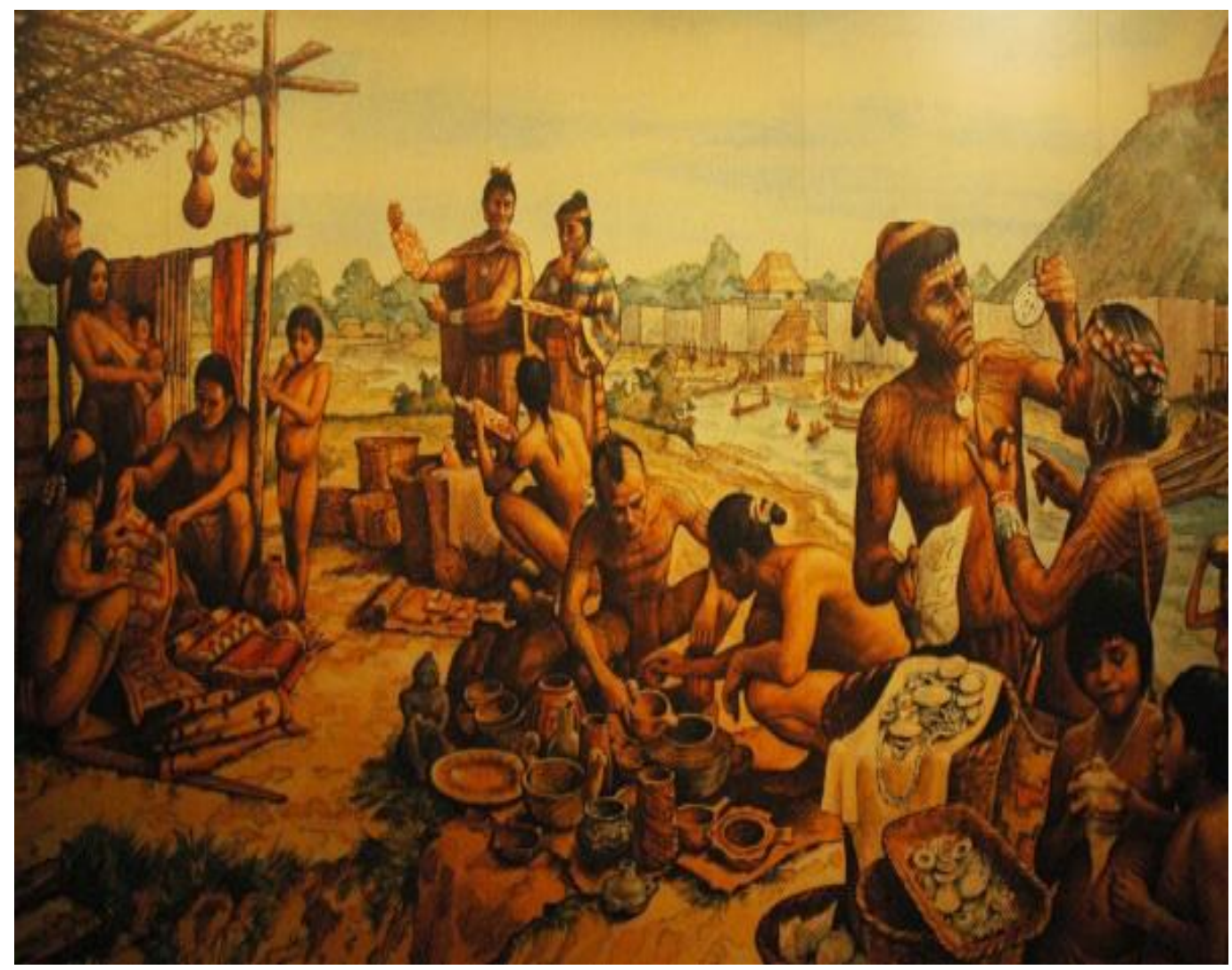

Fig 6 : Rituals of Cahokia

Today we look at Cahokia with boundless curiosity. With Each day, new scientific technique, new technologies, new ideas help us to understand the culture that ruled this valley for hundreds of years. But still, there are many mysteries to unravel.

\section{FALL OF THE CIVILIZATION}

No one knows exactly why Cahokia began to decline, sometime in late 13 th century or early 14 th century. We know that the end came slowly over many years as Cahokia's authority and powers were challenged. We know that poor nutrition and diseases were only few of the many growing problems. Maybe changes in climate, dwindling resources and growing population or perhaps war fares and conflicts within the groups or from the outside also led to its decline [7]. 


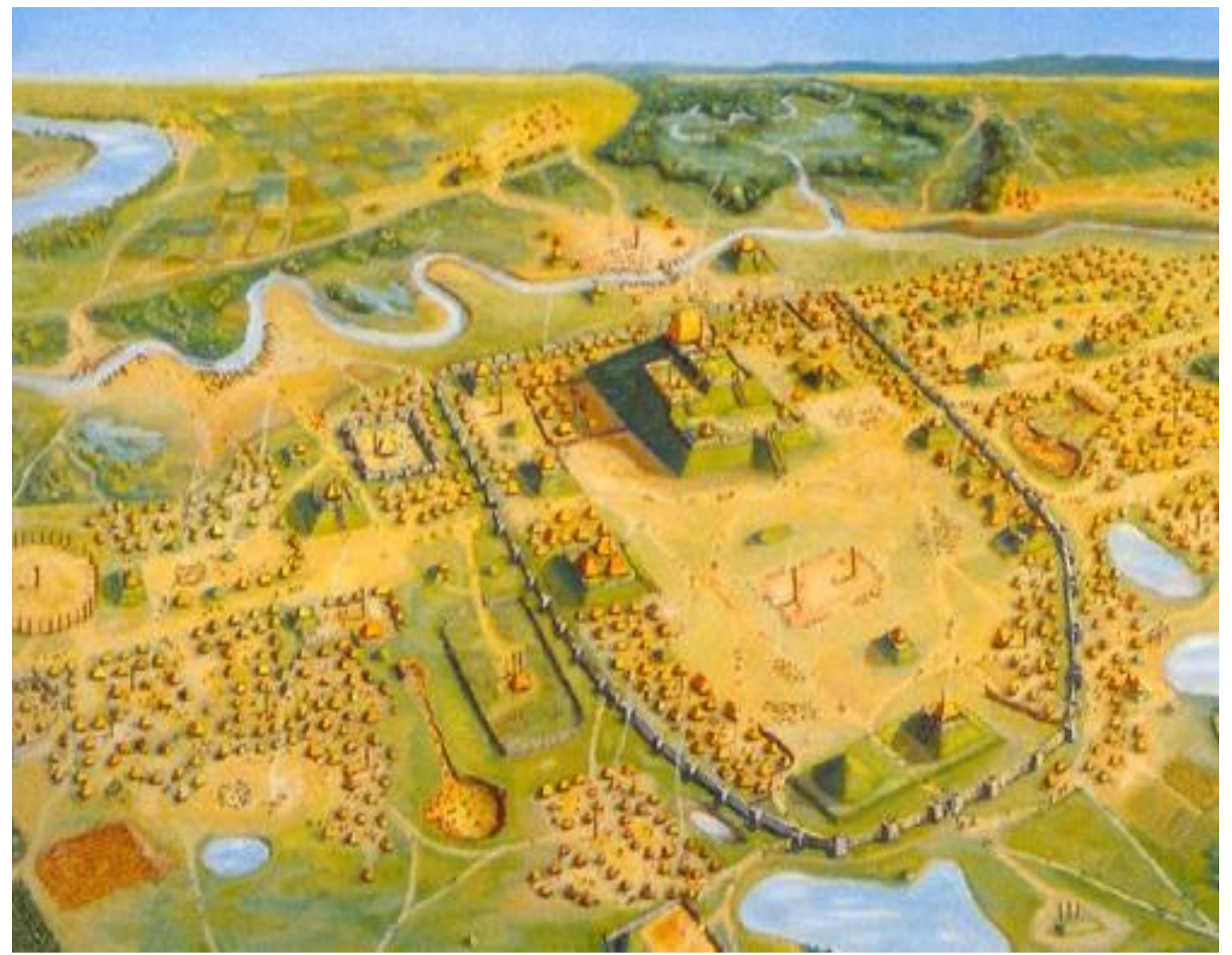

Fig 7 : The Great Kahokia

\section{CONCLUSION}

These mysteries endure and challenge us to think harder, to reach back with the power of mind's eye to a time long ago when the embers were fed by the sacred fire, glowed and moulded through the night. In those days the earth was bountiful, many fires warmed them, and they planted maize and prayed for blessings from the rain and the sun. They travelled far, saw fine houses and great temples but wherever they went, they found sounds of the greatness of their home because none could beat the splendour and majesty of this place. This place grew maize, their runners were most swift and their builders reached the sky. This is Cahokia - the city of the sun where the sun shone most brightly.

\section{ACKNOWLEDGEMENTS}

First of all thanks to Prof. K.Mohan, (Sr. Professor, Gitam School of Architecture, Gitam University) for teaching the meaning of Architecture in my B.Arch. days and later, giving me a chance to present my paper in such a wonderful platform. A special thanks to Diksha Jain $\left(1^{\text {st }}\right.$ year Student, Gitam School of Architecture, Gitam University); and Tapasya Mukammala $\left(4^{\text {th }}\right.$ year Student, Gitam School of Architecture, Gitam University) without whom the report would not have been in the desired shape. Thanks to all my students who has always inspired me to explore a new world in the fraternity of Architecture.

\section{REFERENCES}

[1]. Pauketat, T. R. Ancient Cahokia and the Mississippians. Cambridge : Cambridge University Press.

[2]. Site, C. m. (2008). Cahokia mounds state historic site. Retrieved february 27, 2015, from www.cahokiamounds.org: http://www.cahokiamounds.org [3]. Smith, C. (2000, february 1). Cahokia. Retrieved March 1, 2015, from www.cabrilla.edu: http://www.cabrilla.edu [4]. MHQ. (2006, June 12). Cahokian Indians: America's Ancient Warriors. Retrieved February 26, 2015, from www.historynet.com: http://www.historynet.com

[5]. Chickasaw.tv. (2014, April 26). Cahokia. Retrieved March 2, 2015, from www.ancient.edu: http://www.ancient.edu

[6]. Chappel, S. A. (2002). Cahokia: cosmic landscape architecture. Retrieved February 25, 2015, from www.press.uchicago.edu: http://www.press.uchicago.edu [7]. Success, F. (2006, March 31). The rise and fall of Cahokia. Retrieved March 1, 2015, from www.failedsuccess.com: http://www.failedsuccess.com 


\section{BIOGRAPHIES}

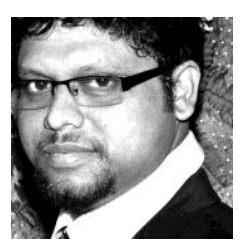

Gaurab Das Mahapatra, Architect, Asst. Professor, Gitam School of Architecture, Gitam University, Visakhapatnam, Andhra Pradesh, India. Ar.Mahapatra's primary focus is to unveil the unknown shades of architectural aspects. He was U.G. thesis topper undertaking the topic "SOCIO ECONOMIC HABITAT" from Piloo Modi College of Architecture in 2012. He feels that society can only be changed if the architecture helps to do so.

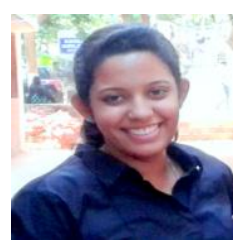

Tapasya Mukkamala, Fourth year student, Gitam School of Architecture, Gitam University, Visakhapatnam Andhra Pradesh, India. Tapasya believes in research oriented learning. Keen interest in urbanism and believes that ancient civilizations play a major role in defining present day urban context.

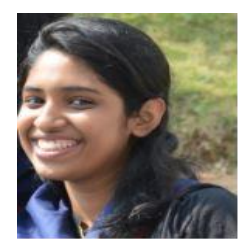

Diksha Jain, $1^{\text {st }}$ Year student, Gitam School of Architecture, Gitam University, Visakhapatnam, Andhra Pradesh, India. Since her introduction into the world of architecture, ancient civilizations have become Diksha Jain's area of interest. 